\title{
Single Crystal X-Ray Diffraction Structure of a Pseudo-polymorph of ( \pm )-3-(ethoxycarbonyl)-2-(imidazol-1-yl) Propionic Acid (IEPA)
}

\author{
Carmen Ubide-Barreda ${ }^{1}$, M. Rosario Torres ${ }^{2} \&$ Paloma Ballesteros $^{1}$ \\ ${ }^{1}$ Laboratorio de Síntesis Orgánica e Imagen Molecular por Resonancia Magnética, Facultad de Ciencias, UNED, \\ Unidad Asociada al CSIC, Madrid, Spain \\ ${ }^{2}$ Centro de Asistencia a la Investigación de Rayos X, Facultad de Ciencias Químicas, Universidad Complutense \\ de Madrid, Ciudad Universitaria, Madrid, Spain \\ Correspondence: Paloma Ballesteros, Laboratorio de Síntesis Orgánica e Imagen Molecular por Resonancia \\ Magnética, Facultad de Ciencias, UNED, Po Senda del Rey 9, Madrid 28040, Spain. Tel: 34-913-987-320. \\ E-mail: pballesteros@ccia.uned.es
}

Received: January 9, 2013 Accepted: February 27, 2013 Online Published: April 2, 2013

doi:10.5539/ijc.v5n2p1 URL: http://dx.doi.org/10.5539/ijc.v5n2p1

\begin{abstract}
( \pm )-3-(Ethoxycarbonyl)-2-(imidazol-1-yl) propionic acid (IEPA) crystallized in two different forms when recrystallized from absolute ethanol (Form I) or water (Form II), respectively. The single crystal X ray diffraction study of Form II unambiguously established that IEPA yielded a pseudopolymorph with a different crystalline packing when crystallized from water. This behaviour is additionally confirmed by Differential Scanning Calorimetry (DSC) and Thermogravimetry (TG).
\end{abstract}

Keywords: Polymorphism, single crystal X-ray analysis, crystalline packing, thermal analysis

\section{Introduction}

$( \pm)$-3-(Ethoxycarbonyl)-2-(imidazol-1-yl) propionic acid (IEPA) (Figure 1) is currently the most appropriate extrinsic probe for non-invasive, preclinical measurements of extracellular $\mathrm{pH}$ by magnetic resonance ${ }^{1} \mathrm{H}$ spectroscopic imaging (MRSI) methods (Gil, Zaderenko, Cruz, Cerdán, \& Ballesteros, 1994; Pacheco-Torres et al., 2011; Hashim, Zhang, Wojtkowiak, Martinez, \& Gillies, 2011). Furthermore, it has been recently proposed as a convenient therapeutic buffer for the treatment of cancer and metastasis (Hashim et al., 2011).

Detailed analyses of crystal structures and intra and intermolecular interactions are essential for the complete characterization and understanding of the functional properties of solids, as well as for the design of new materials (Hilfiker, 2006). We have described previously that IEPA, crystallized in two different forms when it was recrystallized either from absolute ethanol (Form I) or water (Form II) (Ubide-Barreda, Rojas, Martínez-de Paz, Righi, \& Ballesteros, 2011). Comparison of powder X-ray diffraction pattern of Form I and that from Form II, showed clearly that the structures obtained in both cases were different.

In order to confirm this interesting feature we have performed here the single crystal X-ray diffraction analysis of Form II. This information will be useful to prepare and characterize improved IEPA formulations for oral administration (Hashim et al., 2011).

\section{Material and Methods}

\subsection{Synthesis of (土)-3-(Ethoxycarbonyl)-2-(imidazol-1-yl) Propionic Acid (IEPA)}

Synthesis of IEPA was performed from imidazole and diethyl fumarate according to our previous report (Zaderenko, Gil, Ballesteros, \& Cerdán, 1994.)

\subsection{X-Ray Data Collection and Structure Refinement}

Data collection was carried out at room temperature on a Bruker Smart CCD diffractometer using graphite-monochromated Mo-K $\alpha$ radiation $(\lambda=0.71073 \AA)$ operating at $50 \mathrm{kV}$ and $35 \mathrm{~mA}$. The data were collected over a hemisphere of the reciprocal space by combination of three exposure sets. Each exposure of $20 \mathrm{~s}$ covered 0.3 in $\omega$. The cell parameters were determined and refined by a least-squares fit of all reflections. The first 100 frames were recollected at the end of the data collection to monitor crystal decay, and no appreciable 
decay was observed. A summary of the fundamental crystal and refinement data is given in Table 1.

The structure was solved by direct methods and refined by full-matrix least-square procedures on $\mathrm{F}^{2}$ (SHELXL-97) (Sheldrick, 1997). All non-hydrogen atoms were refined anisotropically.

The hydrogen atoms were included in their calculated positions and refined riding on the respective carbon atoms with the exception of hydrogens H5A and H5B bonded to $\mathrm{O} 5$ that were located in a Fourier synthesis and refined riding on the respective bonded atoms.

Further crystallographic details for the structure reported in this paper may be obtained from the Cambridge Crystallographic Data Center, on quoting the depository number CCDC-852977.

Table 1. Crystal data and structure refinement for $\mathrm{C}_{9} \mathrm{H}_{14} \mathrm{~N}_{2} \mathrm{O}_{5}$

\begin{tabular}{|c|c|c|}
\hline Identification code & \multicolumn{2}{|l|}{ iepaH2O } \\
\hline Empirical formula & \multicolumn{2}{|l|}{$\mathrm{C}_{9} \mathrm{H}_{14} \mathrm{~N}_{2} \mathrm{O}_{5}$} \\
\hline Formula weight & \multicolumn{2}{|l|}{230.22} \\
\hline Temperature & \multicolumn{2}{|l|}{$296(2) \mathrm{K}$} \\
\hline Wavelength & \multicolumn{2}{|l|}{$0.71073 \AA$} \\
\hline Crystal system & \multicolumn{2}{|l|}{ Monoclinic } \\
\hline Space group & \multicolumn{2}{|l|}{$\mathrm{P} 2(1) / \mathrm{c}$} \\
\hline \multirow{3}{*}{ Unit cell dimensions } & $\mathrm{a}=4.9692(10) \AA$ & $=90^{\circ}$ \\
\hline & $\mathrm{b}=23.146(5) \AA$ & $=103.046(4)^{\circ}$ \\
\hline & $\mathrm{c}=10.407(2) \AA$ & $=90^{\circ}$ \\
\hline Volume & \multicolumn{2}{|l|}{$1166.1(4) \AA^{3}$} \\
\hline $\mathrm{Z}$ & \multicolumn{2}{|l|}{4} \\
\hline Density (calculated) & \multicolumn{2}{|l|}{$1.311 \mathrm{Mg} / \mathrm{m}^{3}$} \\
\hline Absorption coefficient & \multicolumn{2}{|l|}{$0.108 \mathrm{~mm}^{-1}$} \\
\hline $\mathrm{F}(000)$ & \multicolumn{2}{|l|}{488} \\
\hline Crystal size & \multicolumn{2}{|c|}{$0.45 \times 0.16 \times 0.11 \mathrm{~mm}^{3}$} \\
\hline Theta range for data collection & \multicolumn{2}{|c|}{1.76 to $26.00^{\circ}$} \\
\hline Index ranges & \multicolumn{2}{|c|}{$-6<=\mathrm{h}<=6,-28<=\mathrm{k}<=28,-11<=1<=12$} \\
\hline Reflections collected & \multicolumn{2}{|l|}{9449} \\
\hline Independent reflections & \multicolumn{2}{|c|}{$2266[\mathrm{R}(\mathrm{int})=0.0668]$} \\
\hline Completeness to theta $=26.00^{\circ}$ & \multicolumn{2}{|c|}{$99.1 \%$} \\
\hline Refinement method & \multicolumn{2}{|c|}{ Full-matrix least-squares on $\mathrm{F}^{2}$} \\
\hline Data/restraints/parameters & \multicolumn{2}{|c|}{$2266 / 0 / 145$} \\
\hline Goodness-of-fit on $\mathrm{F}^{2}$ & \multicolumn{2}{|l|}{1.015} \\
\hline Final R index $[I>2 \operatorname{sigma}(I)]$ & \multicolumn{2}{|c|}{$\mathrm{R} 1=0.0502, \mathrm{wR} 2=0.1269$} \\
\hline $\mathrm{R}$ index (all data) & \multicolumn{2}{|c|}{$\mathrm{R} 1=0.1196, \mathrm{wR} 2=0.1594$} \\
\hline Theta range for data collection & \multicolumn{2}{|c|}{1.76 to $26.00^{\circ}$} \\
\hline Index ranges & \multicolumn{2}{|c|}{$-6<=\mathrm{h}<=6,-28<=\mathrm{k}<=28,-11<=\mathrm{l}<=12$} \\
\hline Reflections collected & \multicolumn{2}{|c|}{9449} \\
\hline Independent reflections & \multicolumn{2}{|c|}{$2266[\mathrm{R}(\mathrm{int})=0.0668]$} \\
\hline Completeness to theta $=26.00^{\circ}$ & \multicolumn{2}{|c|}{$99.1 \%$} \\
\hline Refinement method & \multicolumn{2}{|c|}{ Full-matrix least-squares on $\mathrm{F}^{2}$} \\
\hline Data/restraints/parameters & $2266 / 0 / 145$ & \\
\hline Goodness-of-fit on $\mathrm{F}^{2}$ & 1.015 & \\
\hline Final R index [I $>2 \operatorname{sigma}(I)]$ & $\mathrm{R} 1=0.0502, \mathrm{wR}$ & \\
\hline $\mathrm{R}$ index (all data) & $\mathrm{R} 1=0.1196, \mathrm{wR}$ & \\
\hline
\end{tabular}




\subsection{Thermal Analysis (TG and DSC)}

Thermal analysis was carried out using a Seiko SSC 5200 TG-TA 320 System. A Sample of Form II (about 20 $\mathrm{mg}$ ) was heated in nitrogen from $30 \mathrm{up}$ to $125^{\circ} \mathrm{C}$ (flow rate $=50 \mathrm{~mL} \cdot \mathrm{min}^{-1}$ ) with a heating rate of $10^{\circ} \mathrm{C} \cdot \mathrm{min}^{-1}$, soaked at this temperature for $3 \mathrm{~min}$, then heated up to $160{ }^{\circ} \mathrm{C}$ at a heating rate of $0.5^{\circ} \mathrm{C} \cdot \mathrm{min}^{-1}$ and finally from 160 up to $400{ }^{\circ} \mathrm{C}$ at a heating rate of $10^{\circ} \mathrm{C} \cdot \mathrm{min}^{-1}$.

\section{Results and Discussion}

\subsection{Synthesis of IEPA Form II}

Polymorphs I and II of IEPA were obtained according to previous reports (Ubide-Barreda, Rojas, Martínez-de Paz, Righi, \& Ballesteros 2011).

\subsection{Molecular and Crystal Structure of Form II}

Bond distances and angles of Form II (Figure 1) are similar to those of Form I described previously (López et al., 1996). Tables 2 and 3 summarize bonds, angles, hydrogen bonds and torsion angles obtained from single crystal X-ray analysis of IEPA Form II.

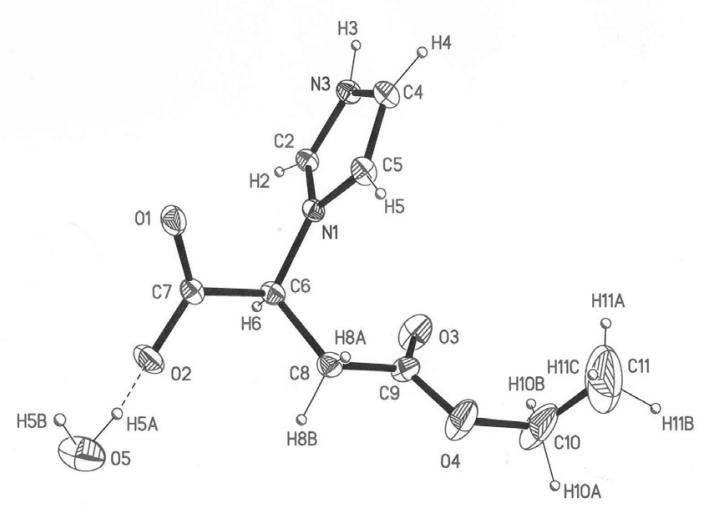

Figure 1. ORTEP view of IEPA (Form II) showing the atomic numbering; displacement ellipsoids are drawn at the $20 \%$ probability level

The IEPA Form II forms intermolecular hydrogen bonds between the carboxylate O1 and the imidazole N3 of a neighbouring molecule with parameters $\mathrm{N} 3-\mathrm{H} 3 \quad 1.06 \AA$, H3 $\cdots \mathrm{O} 11.63 \AA$ and $\mathrm{N} 3-\mathrm{H} 3-\mathrm{O} 1{ }^{169.2^{\circ}}$ angle. Intermolecular bonding of the adjacent molecules originates the formation of zig-zag chains. This zig-zag arrangement is due to the torsion found in the molecule between the carboxylate and imidazole planes of $77.3(2)^{\circ}$.

The chains are connected by hydrogen bonds involving the water molecules and the second oxygen atom of the carboxylate group with distances O5 $\cdots \mathrm{O} 2=2.936(4) \AA$ and $\mathrm{O} 5 \cdots \mathrm{O} 2{ }^{\prime}=2.903(3) \AA$. This interaction is extended along the "a" crystal axis. It becomes important to remark here the importance of the water molecule interactions in the stabilization of the crystal packing of Form II (Figure 2a). No intermolecular interactions are found involving the ester carboxylate oxygen. 
Table 2. Geometric parameters ( $\AA$,deg) for compound ( \pm )-3-(ethoxycarbonyl)-2-(imidazol-1-yl) propionic acid crystallized from water

\begin{tabular}{|c|c|c|c|c|}
\hline Bond & Bond lengths $(\AA)$ & & Angle & (deg) \\
\hline $\mathrm{N} 1-\mathrm{C} 2$ & $1.335(2)$ & & C5-N1-C6 & $124.2(1)$ \\
\hline N1-C5 & $1.378(2)$ & & C2-NI-C6 & $128.3(1)$ \\
\hline N1-C6 & $1.468(2)$ & & C2-NI-C5 & $107.5(1)$ \\
\hline C2-N3 & $1.314(2)$ & & NI-C2-N3 & $109.7(1)$ \\
\hline N3-C4 & $1.370(2)$ & & C2-N3-C4 & $108.2(1)$ \\
\hline $\mathrm{C} 4-\mathrm{C} 5$ & $1.350(2)$ & & N3-C4-C5 & $107.6(1)$ \\
\hline C6-C7 & $1.544(2)$ & & NI-C5-C4 & $107.0(1)$ \\
\hline C6-C10 & $1.525(2)$ & & $\mathrm{NI}-\mathrm{C} \sim \mathrm{CIO}$ & $111.6(1)$ \\
\hline $\mathrm{C} 7-\mathrm{O} 8$ & $1.229(2)$ & & NI-C6-C7 & 113.1(1) \\
\hline C7-O9 & $1.257(2)$ & & C7-C6-CI0 & $113.3(1)$ \\
\hline C10-C11 & $1.502(2)$ & & C6-C7-09 & $111.6(1)$ \\
\hline C11-O12 & $1.202(2)$ & & C6-C7-08 & $120.5(1)$ \\
\hline C11-O13 & $1.332(2)$ & & 08-C7-09 & $127.8(1)$ \\
\hline O13-C14 & $1.456(3)$ & & C6-C10-C11 & $114.0(1)$ \\
\hline \multirow[t]{5}{*}{ C14-C15 } & $1.496(5)$ & & C10-C11-O13 & $110.4(1)$ \\
\hline & & & $\mathrm{C} 10-\mathrm{C} 11-\mathrm{O} 12$ & $125.8(2)$ \\
\hline & & & O12-C11-O13 & $123.8(2)$ \\
\hline & & & C11-OI3-CI4 & $116.4(2)$ \\
\hline & & & OI3-CI4-C15 & $106.2(3)$ \\
\hline \multicolumn{5}{|l|}{ Hydrogen bonds } \\
\hline D-H...A & $\mathrm{d}(\mathrm{D}-\mathrm{H})$ & $d(H \ldots A)$ & d(D...A) & $<(\mathrm{DHA})$ \\
\hline $\mathrm{O}(5)-\mathrm{H}(5 \mathrm{~B}) \ldots \mathrm{O}(2) \# 1$ & 1.05 & 1.89 & $2.903(3)$ & 160.7 \\
\hline $\mathrm{O}(5)-\mathrm{H}(5 \mathrm{~A}) \ldots \mathrm{O}(2)$ & 1.09 & 1.86 & $2.936(4)$ & 166.6 \\
\hline $\mathrm{N}(3)-\mathrm{H}(3) \ldots \mathrm{O}(1) \# 2$ & 1.06 & 1.63 & $2.677(3)$ & 169.2 \\
\hline \multicolumn{4}{|c|}{ Symmetry transformations used to generate equivalent atoms: } & \\
\hline
\end{tabular}

Table 3. Torsion angles $\left[{ }^{\circ}\right]$

\begin{tabular}{crcr}
\hline \multicolumn{1}{c}{ Torsion angles } & \multicolumn{1}{c}{ Degree $\left({ }^{\circ}\right)$} & Torsion angles & \multicolumn{1}{c}{ Degree $\left(^{\circ}\right)$} \\
\hline $\mathrm{N}(3)-\mathrm{C}(4)-\mathrm{C}(5)-\mathrm{N}(1)$ & $0.5(3)$ & $\mathrm{C}(4)-\mathrm{C}(5)-\mathrm{N}(1)-\mathrm{C}(6)$ & $-179.1(3)$ \\
$\mathrm{N}(1)-\mathrm{C}(6)-\mathrm{C}(7)-\mathrm{O}(1)$ & $-4.8(4)$ & $\mathrm{C}(8)-\mathrm{C}(6)-\mathrm{N}(1)-\mathrm{C}(2)$ & $134.5(3)$ \\
$\mathrm{C}(8)-\mathrm{C}(6)-\mathrm{C}(7)-\mathrm{O}(1)$ & $120.5(3)$ & $\mathrm{C}(7)-\mathrm{C}(6)-\mathrm{N}(1)-\mathrm{C}(2)$ & $-101.1(3)$ \\
$\mathrm{N}(1)-\mathrm{C}(6)-\mathrm{C}(7)-\mathrm{O}(2)$ & $174.0(3)$ & $\mathrm{C}(8)-\mathrm{C}(6)-\mathrm{N}(1)-\mathrm{C}(5)$ & $-47.2(4)$ \\
$\mathrm{C}(8)-\mathrm{C}(6)-\mathrm{C}(7)-\mathrm{O}(2)$ & $-60.7(4)$ & $\mathrm{C}(7)-\mathrm{C}(6)-\mathrm{N}(1)-\mathrm{C}(5)$ & $77.2(3)$ \\
$\mathrm{N}(1)-\mathrm{C}(6)-\mathrm{C}(8)-\mathrm{C}(9)$ & $-53.8(3)$ & $\mathrm{N}(1)-\mathrm{C}(2)-\mathrm{N}(3)-\mathrm{C}(4)$ & $0.0(3)$ \\
$\mathrm{C}(7)-\mathrm{C}(6)-\mathrm{C}(8)-\mathrm{C}(9)$ & $-179.1(3)$ & $\mathrm{C}(5)-\mathrm{C}(4)-\mathrm{N}(3)-\mathrm{C}(2)$ & $-0.3(3)$ \\
$\mathrm{C}(6)-\mathrm{C}(8)-\mathrm{C}(9)-\mathrm{O}(3)$ & $-11.8(5)$ & $\mathrm{O}(3)-\mathrm{C}(9)-\mathrm{O}(4)-\mathrm{C}(10)$ & $1.9(6)$ \\
$\mathrm{C}(6)-\mathrm{C}(8)-\mathrm{C}(9)-\mathrm{O}(4)$ & $166.6(3)$ & $\mathrm{C}(8)-\mathrm{C}(9)-\mathrm{O}(4)-\mathrm{C}(10)$ & $-176.5(4)$ \\
$\mathrm{N}(3)-\mathrm{C}(2)-\mathrm{N}(1)-\mathrm{C}(5)$ & $0.3(3)$ & $\mathrm{C}(11)-\mathrm{C}(10)-\mathrm{O}(4)-\mathrm{C}(9)$ & $104.9(6)$ \\
$\mathrm{N}(3)-\mathrm{C}(2)-\mathrm{N}(1)-\mathrm{C}(6)$ & $178.9(2)$ & $\mathrm{C}(5)-\mathrm{C}(4)-\mathrm{N}(3)-\mathrm{C}(2)$ & $-0.3(3)$ \\
$\mathrm{C}(4)-\mathrm{C}(5)-\mathrm{N}(1)-\mathrm{C}(2)$ & $-0.5(3)$ & $\mathrm{O}(3)-\mathrm{C}(9)-\mathrm{O}(4)-\mathrm{C}(10)$ & $1.9(6)$ \\
\hline
\end{tabular}




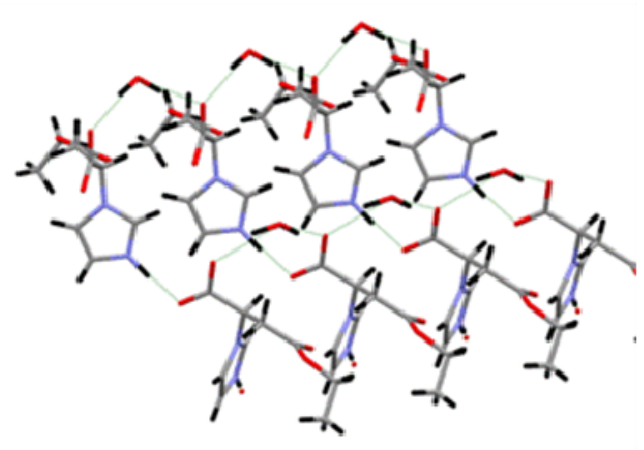

(a)

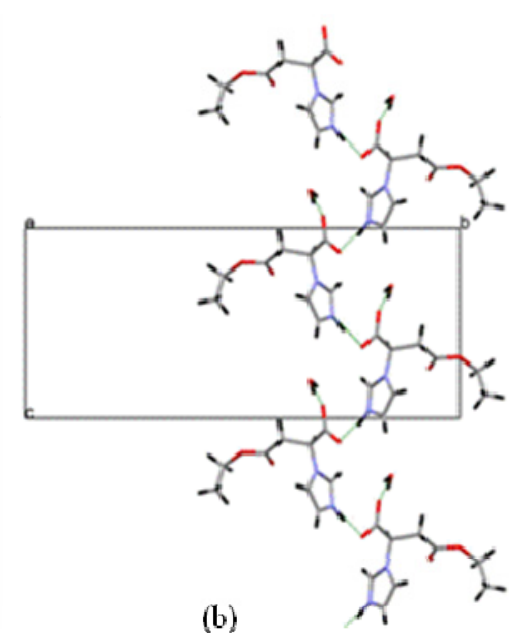

(b)

Figure 2. Crystal packing of Form II. (a) Three-dimensional view of the zig-zag chains (b) View of one zig-zag chain along the "a" axis

\subsection{Thermal Analysis (TG and DSC)}

Figure 3 shows the thermogravimetric (TG) and differential scanning calorimetry (DSC) curves of Form II. The TG curve of the hydrated form II shows two mass losses. The first one, occurring in a range of $40{ }^{\circ} \mathrm{C}-70{ }^{\circ} \mathrm{C}$, is $6 \%$. This loss can be attributed to the loss of water by drying, since the sample is wet to prevent structural degradation. The second mass loss, in a temperature range of $70{ }^{\circ} \mathrm{C}-140{ }^{\circ} \mathrm{C}$ reaching $6 \%$, is attributed to the removal of the water molecules of crystallization. However, we have previously reported a mass loss of $3 \%$ at 60-100 ${ }^{\circ} \mathrm{C}$ (Ubide-Barreda, Rojas, Martinez-de Paz, Righi, \& Ballesteros, 2011). This variation is most likely due to a different degree of humidity in the conservation of the earlier sample and a consequent partial degradation associated to the smaller water loss. The DSC curve shows three different endothermic peaks. The first one at $70{ }^{\circ} \mathrm{C}$, with a heat of $36 \mathrm{~kJ} / \mathrm{mol}$, is due to the rearrangement of the molecular structure involving; the breaking of zwitterionic interactions, the rupture of ring interactions within neighboring chains and the evaporation of moisture. The second peak centered at $120^{\circ} \mathrm{C}$, with a heat $15 \mathrm{~kJ} / \mathrm{mol}$., is associated with the loss of water molecules within the crystal structure and the melting point process. Finally, the third peak centred at $260{ }^{\circ} \mathrm{C}$ is associated to the decomposition leaving a carbonaceous residue of $13 \%$.

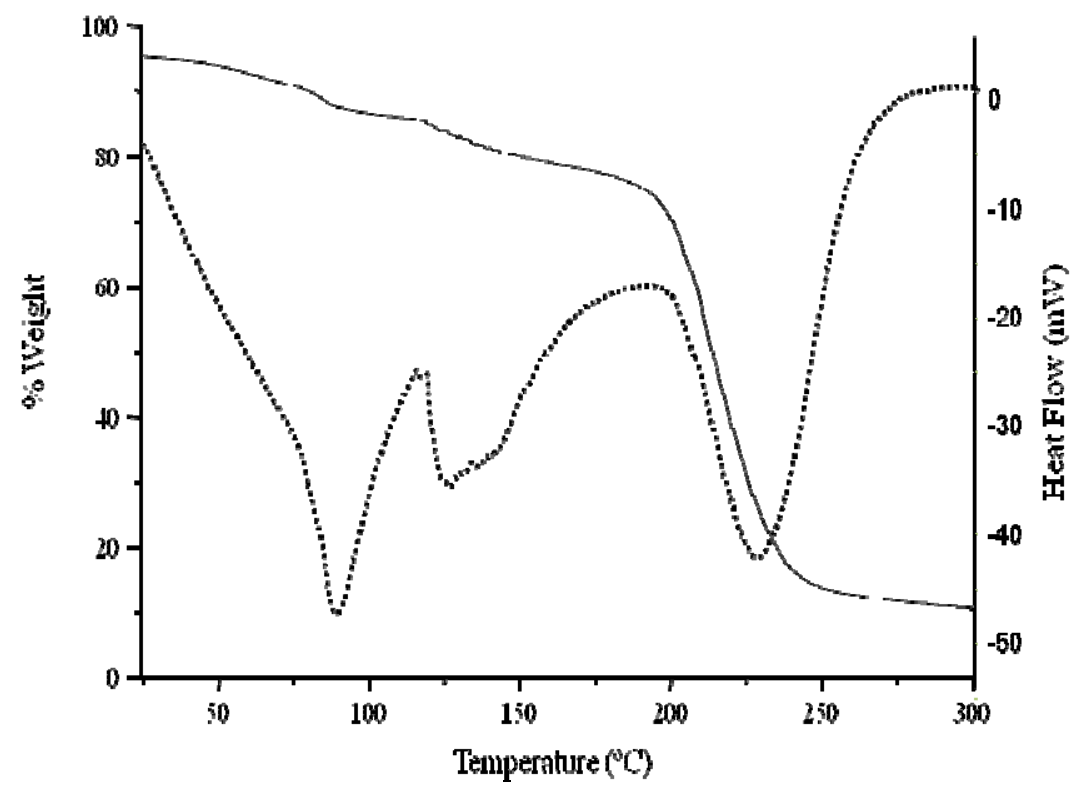

Figure 3. TG (solid line) and DSC (dotted line ) thermograms of Form II 


\section{Conclusions}

The results obtained from single crystal X-ray diffraction study of Form II confirm unambiguously that ( \pm )-3-(ethoxycarbonyl)-2-(imidazol-1-yl)propionic acid (IEPA) yields a pseudopolymorph when crystallized from water. The chains in the crystal are connected by hydrogen bonds involving the water molecules and the second oxygen atom of the carboxylate group with distances O5 $\cdots \mathrm{O} 2=2.936(4) \AA$ and $\mathrm{O} 5 \cdots \mathrm{O} 2{ }^{\prime}=2.903(3) \AA$. This interaction is extended along the "a" crystal axis. The presence of water in the solvate is also confirmed by thermogravimetry. The results obtained herein will be useful to prepare and characterize new IEPA formulations for oral administration with improved bioavailability.

\section{Acknowledgements}

This work was supported in part by grants: CTQ2010-20960-C02-01, S2010/BMD-2349, MICINN-PTA 2010-03023-I to C.U.

\section{References}

Gil, S., Zaderenko, P., Cruz, F., Cerdán, S., \& Ballesteros, P. (1994). Imidazol-1-ylalkanoic Acids as Extrinsic ${ }^{1} \mathrm{H}$ NMR Probes for the determination of Intracellular $\mathrm{pH}$, extracellular $\mathrm{pH}$ and Cell Volume. Bioorg. Med. Chem., 2, 305-314. http://dx.doi.org/10.1016/S0968-0896(00)82186-0

Hashim, A. I., Cornnell, H. H., Coelho-Ribeiro, M. L., Abrahams, D., Cunningham, J., Lloyd, M., ... Gillies, R. (2011). Reduction of metastasis using a non-volatile buffer. Clin. Exp. Metastasis, 28, 841-849. http://dx.doi.org/10.1007/s10585-011-9415-7

Hashim, A. I., Zhang, X., Wojtkowiak, J. W., Martinez, G. V., \& Gillies, R. J. (2011). Imaging pH and metastasis. NMR Biomed, 24, 582-591. http://dx.doi.org/10.1002/nbm.1644

Hilfiker, R. (2006). Polymorphism in the Pharmaceutical Industry. Weinheim: Wiley-VCH.

López, P., Zaderenko, P., Balcazar, J. L., Fonseca, I., Hernández-Cano, F., \& Ballesteros, P. (1996). The zwitterion structure of imidazol-1-ylacetic acids in the solid state and in solution. J. Mol. Struct, 377, 105-112. http://dx.doi.org/10.1016/0022-2860(95)09118-1

Pacheco-Torres, J., Calle, D., Lizarbe, B., Negri, V., Ubide, C., Fayos, R., ... Cerdan, S. (2011). Environmentally Sensitive Paramagnetic and Diamagnetic Contrast Agents for Nuclear Magnetic Resonance Imaging and Spectroscopy. Curr. Top. Med. Chem, 11, 115-130. http://dx.doi.org/10.2174/156802611793611904

Sheldrick, G. M. (1997). SHELX97, Program for Refinement of Crystal Structure. University of Göttingen, Göttingen, Germany.

Ubide-Barreda, C., Rojas, M. L., Martínez-de Paz, P. J., Righi, V., \& Ballesteros, P. (2011). Polymorphism of racemic imidazol-1-ylsuccinic acid derivatives. Suitable probes for extracellular $\mathrm{pH}$ by magnetic resonance spectroscopic imaging. ARKIVOC, (iii), 179-190.

Zaderenko, P., Gil, M. S., Ballesteros, P., \& Cerdán, S. (1994). Synthesis and Regioselective Hydrolysis of 2-Imidazol-1-ylsuccinic Esters. J. Org. Chem., 59, 6268-6273. http://dx.doi.org/10.1021/jo00100a030 